\author{
N.I. Kopylov \\ Institute of Solid State Chemistry and Mechanochemistry \\ of the Siberian Branch of the Russian Academy of Sciences, Novosibirsk, Russia \\ (E-mail:kolyubov@narod.ru)
}

\title{
Phase decomposition of coals of the Tavantolgoyskoye deposit of Mongolia during their roasting
}

\begin{abstract}
Coals of the Tavantolgoyskoye deposit, by analogy with the coals of other similar deposits, are of interest not only as a fuel and energy resource, but also as raw materials for the metallurgical and chemical industries. In order to prevent contamination of the environment with toxic components when using these coals as fuel for thermal power plant and domestic furnace installations, as well as in industry as a raw material, their special preparation is required. In this regard, investigations were carried out to study the phase decomposition of these coals during their roasting. The results of a comprehensive study of the thermal decomposition of hard coal from this deposit are presented. It is established that this process of phase decomposition is carried out within the temperature range of $300-500{ }^{\circ} \mathrm{C}$ with the release of gas, low-melting and low-boiling phases. At the same time, the mass of the material increases in volume and is sintered with the formation of a solid, porous sinter, the volume of which is 1.5-2 times higher than the volume of the initial sample. It is shown that tavantolgoysky coal can be used to produce fuel briquettes without the addition of a binder.
\end{abstract}

Keywords: coal, phase decomposition, solid residue, resinous fraction, condensate, sublimates, organic fraction.

\section{Introduction}

Coals of the Tavantolgoyskoye deposit in Mongolia, by analogy with the coals of other developed deposits, can be valuable raw materials not only for the power industry, but also for the metallurgical and chemical industries [1,2]. However, the effectiveness of the development of proven reserves is hampered by the high cost of coal mined, and industrial use is hampered by remoteness from industrial centers and the lack of proper transportation routes. Therefore, these coals, as well as products of other fields in Central Asia (for example, Tuva, etc.), are used mainly as fuel for heat and power engineering and private sector units. So, 2.45 million tons were produced for the needs of nearby aimaks and local consumption in the period from 1967 to 2004. In 2006, production amounted to 787.1 thousand tons [3, 4].

The dynamics and nature of thermal decomposition of fossil coal is determined by their composition $[1,2]$. Depending on the chemical and phase composition, structure and type of coal, when it is heated, noncondensible gas fractions are removed from the material in a certain sequence, melting and sublimation of condensable products of thermal decomposition takes place. During the coal burning due to incomplete combustion and the formation of sintering with flue gases, the products of this incomplete combustion, in particular, dispersed soot, are emitted into the atmosphere, the particles of toxic decomposition products of coal are sorbed on the surface of the particles. This leads to the release into the environment of environmentally hazardous substances.

The complex geological conditions and extreme continental climate of Central Asia contribute to the formation of stagnant air zones, smog in confined spaces of intermountain valleys. All this leads to the pollution of the atmosphere of rural and urban settlements in these regions by harmful products of flue gases with high concentrations of toxic substances, including carcinogenic polyaromatic hydrocarbons, whose concentrations reach $\mathrm{X} \mathrm{g} / \mathrm{kg}[5]$.

The production and use of environmentally friendly dry coal briquettes will reduce harmful emissions into the atmosphere and reduce the degree of damage to the environment. The resulting thermolysis products can be used to produce mineral oils, motor fuels, and other chemical products. In this regard, in order to obtain baseline data for the technology of producing fuel briquettes for a number of years we have carried out studies on the thermal decomposition of coal from deposits of Tuva and Mongolia [6-8]. This report presents the results of a study of the phase decomposition of hard coal from the Tavantolgoyskoye deposit in Mongolia. 


\section{Experimental}

The object of study was the material of the Tavantolgoyskoye coal deposit (Mongolia) in the form of an average finely ground $(\sim 0.02 \mathrm{~mm})$ sample of reservoir VIII, a single lump sample of formation IV and an enlarged average lumpy sample of the field. Technical characteristics and elemental composition of the studied coal samples VIII and IV are presented in Table 1.

T a b l e 1

Technical characteristics and elemental composition of samples of Tavantolgoysky coal

\begin{tabular}{|l|c|c|c|c|c|c|c|}
\hline \multirow{2}{*}{ Samples } & \multicolumn{2}{|c|}{ Technical specifications, \% } & \multicolumn{3}{c|}{ Elemental composition, \% } & \multirow{2}{*}{$\mathrm{Q}_{\mathrm{s}}^{\mathrm{a}}$} \\
\cline { 2 - 8 } & $\mathrm{W}^{\mathrm{a}}$ & $\mathrm{A}^{\mathrm{a}}$ & $\mathrm{V}^{\text {daf }}$ & $\mathrm{C}^{\text {daf }}$ & $\mathrm{H}^{\text {daf }}$ & $\mathrm{S}_{\text {gen }}$ & $\mathrm{kcal} / \mathrm{kg}$ \\
\hline Seam IV & 0.9 & 10.6 & 30.1 & 84.0 & 5.4 & 0.67 & 6828.3 \\
\hline Seam VIII & 0.9 & 14.7 & 35.8 & 76.0 & 4.4 & 0.69 & 6763.5 \\
\hline
\end{tabular}

Thermal analysis was performed using a derivator of the model «Paulik, Paulik-Erdey», type IOM-1000 (Hungary). The maximum heating temperature was limited to $650-700{ }^{\circ} \mathrm{C}$. The heating rate was maintained at $10^{\circ} \mathrm{C} / \mathrm{min}$. The magnitude of the sample was $1.0 \pm 0.2 \mathrm{~g}$. Experiments were carried out under conditions that ensure free diffusion of the gas components and prevent contact of the material with the air medium.

Determination of quantitative and aggregate changes in the heating process with capturing sublimates of coal fractions was carried out in a laboratory setup that includes a furnace with a reactor in which a crucible with a weight of 50-100 g was placed and collector of condensed sublimates connected to it with the help of a branch pipe.

DTGA samples of coal seam VIII.

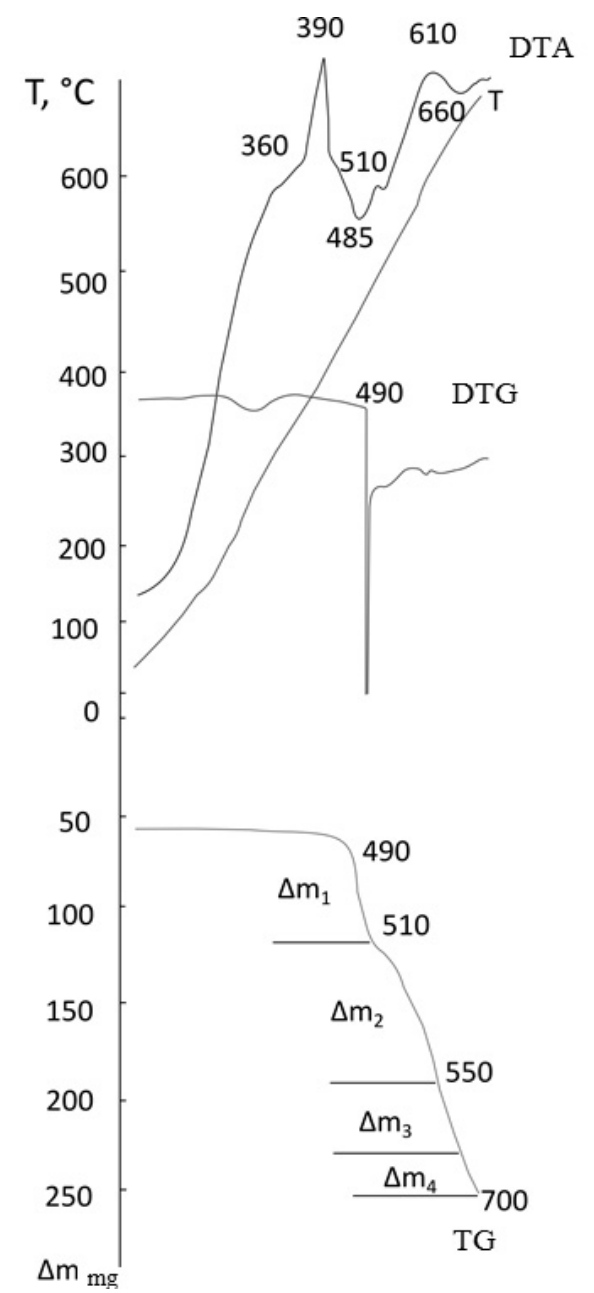

Figure 1. DTGA of the initial sample of reservoir VIII 
The beginning of thermal decomposition (Fig. 1) is marked a sharp explosive endoeffect (at 420 $490{ }^{\circ} \mathrm{C}$ ) associated with the evolution of gaseous components (with a weight loss of 5-7\%) and at the same time the appearance of a low-melting fraction. The subsequent stages of thermolysis possess monotonous step character. The total weight loss is $14-15 \%$. A characteristic feature of the thermolysis of this sample is the appearance of an acute exo peak on the DTA curve at $360-410^{\circ} \mathrm{C}$, the nature of which was not entirely clear from the start. This effect does not appear on the TG and DTG curves. Therefore, one would assume that there is a phase or structural transformation with the release of heat. However, more likely, the appearance of this exoeffect is due to heating due to the oxidation reaction of the sample material by sorbed oxygen contained in the starting material with a high degree of dispersion. The process can occur without the formation of gaseous products. In the case of the formation of gaseous products, their removal may be slowed down due to sorption or delayed diffusion.

In all experiments carried out on the whole volume, the material is sintered and compacted.

$D T G A$ samples of coal seam $I V$. Pre-lumpy material was crushed (to a particle size of $\leq 0.5 \mathrm{~mm}$ ). When the sample is heated, exoeffects at 380,500 and $520{ }^{\circ} \mathrm{C}$ and endoeffects at 420,590 and $640{ }^{\circ} \mathrm{C}$ are detected on the DTA curve (Fig. 2).

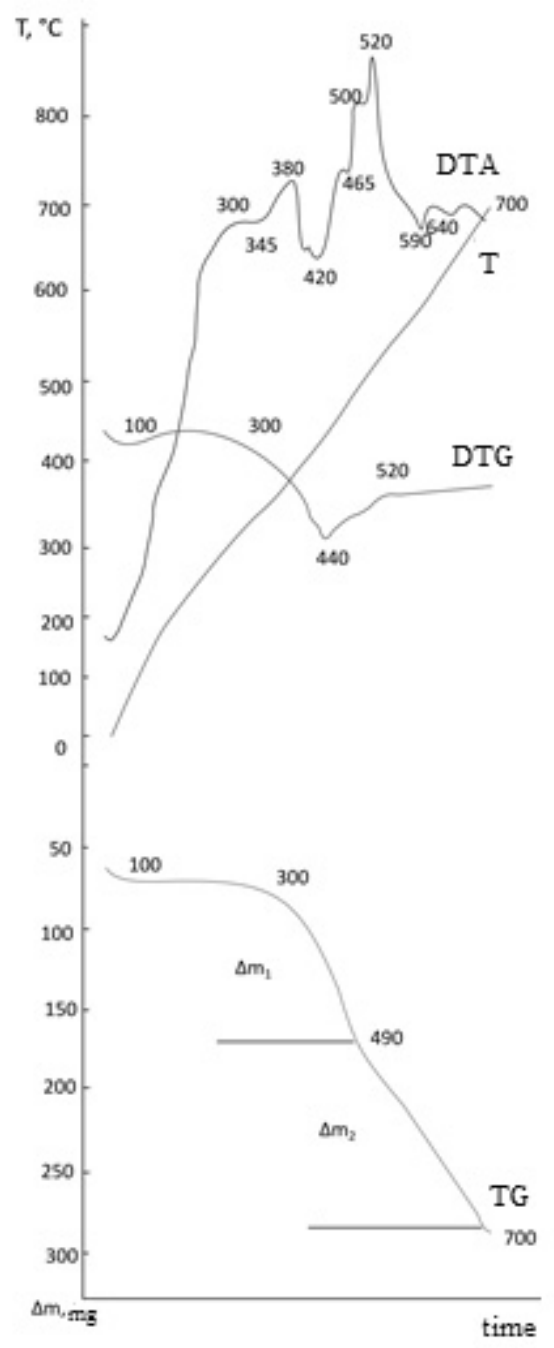

Figure 2. DTGA of the initial sample of reservoir IV

Such dynamics of decomposition is due to the fact that several processes are simultaneously or sequentially realized during heating: an exothermic structural transition, melting, boiling and sublimation of hydrocarbon components, distillation of the gas fraction and its ignition at the crucible exit (exoeffect at 500 $520^{\circ} \mathrm{C}$ ). When this occurs, the sample mass decreases (TG and DTG curves) at $90-100{ }^{\circ} \mathrm{C}$ by $\sim 0.8 \%$, possibly due to the loss of sorbed moisture, and further from $300^{\circ} \mathrm{C}$ with an increase in intensity to $440-480{ }^{\circ} \mathrm{C}$ 
and uniform up to $700{ }^{\circ} \mathrm{C}$. In this case, the total mass loss is equal to $25.8 \%$, which exceeds the mass loss of a sample of coal from reservoir VIII, for the reason that sample IV is prepared from lump monolith, and sample VIII is from the initial dispersed, finely ground material from which, due to a large contact surfaces with the external environment; during storage a significant part of the gas component evaporates. At $450-480^{\circ} \mathrm{C}$, a swelling and increase in the volume of the material occurs with the formation of a viscous mass. When cooled, a sufficiently solid porous column is formed.

DTGA samples of the enlarged batch (mass $\sim 3 \mathrm{~kg}$ ), which consisted of a mixture of fines and a lump material of various sizes, gave the following results.

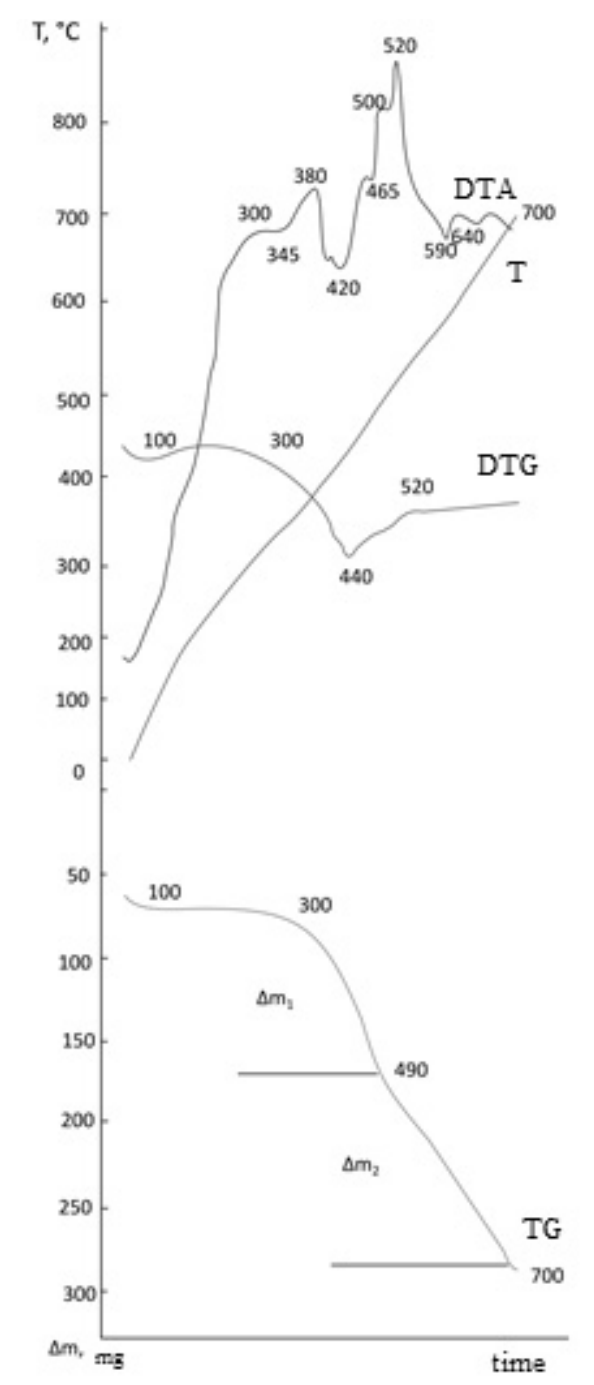

Figure 3. DTGA enlarged batch of coal Tavantolgoyskoye field

When heated, the phase and chemical changes in the material have a complex dynamics (see Fig. 3). Already in the areas of DTA, DTG and TG curves, corresponding to a temperature of $100-140{ }^{\circ} \mathrm{C}$, a small effect is noted, accompanied by a small weight loss. At $\sim 300^{\circ} \mathrm{C}$, the effect appears with a slight increase $(0.5 \%)$ and a subsequent decrease in mass $(\sim 1.8 \%)$. In this temperature range, the total mass loss of the sample was $2.4 \%$.

The subsequent explosive effect at $405-440{ }^{\circ} \mathrm{C}$ is observed on the DTG and DTA curves with a sharp weight loss $\left(\Delta \mathrm{m}^{2} \sim 8.2 \%\right.$ ). Phase transformations (DTA: $480,540,590$ and $610^{\circ} \mathrm{C}$ ) are accompanied by a consistent decrease in mass, a total of $11.0 \%$, and further in the range of $610-680{ }^{\circ} \mathrm{C}-3.5 \%$. The total cumulative mass loss is $\sim 25 \%$. At the same time, intensive swelling of the material, the formation of porous sinter in the upper part of the sample and dense sintering in its bottom part are noted.

Enlarged experiments of thermal decomposition of coal. According to the data of experiments, the mass loss of the sample when heated to $600{ }^{\circ} \mathrm{C}$ and exposure at this temperature is in the range of 29.35-25.45\% 
(average $-22.78 \%$ ), except for the decrease in the mass of the sample prepared from small rashes, equal to $10.45 \%$, which does not fit in with the results of other experiments. This is probably due to the aggregate composition of the source material and the initial low content of the gas component in the composition of the coal. Prolonged contact with the air environment of coal in the form of a small rash contributes to the intensive diffusion of the gas component from coal, as well as chemical and physical weathering of the easily oxidizable and removed to the environment components of this type of coal.

The amount of condensate produced by sublimates of low-boiling fractions on average reaches $\sim 9 \%$ of the initial sample mass. The maximum value $(10.09 \%)$ was obtained in the experiment, where the initial sample was prepared from lump material. At the same time, data on the mass of condensate $(8.9 \%)$ for the experiment, where the source material was trifle from the package of the enlarged batch, agrees well with the data of other experiments.

The results of experiments with heating samples up to $600^{\circ} \mathrm{C}$ with holding for 2 hours every $100{ }^{\circ} \mathrm{C}$ showed that the process of thermal decomposition for averaged samples prepared with the grinding of bulk material of different sizes, and for the sample obtained by grinding a part of the whole monolith, implemented by a single mechanism.

Intensive thermolysis occurs in the temperature range of $400-500{ }^{\circ} \mathrm{C}$ with maximum sublimation of gaseous and easily volatile components of coal within up to $15 \%$ of the initial mass of the sample, from which $10-12 \%$ is due to removal of the gas component, i.e. $70-80 \%$ of the total mass loss of the original sample.

The mass loss of the material when heated to $300{ }^{\circ} \mathrm{C}$ reaches almost $3 \%$ for medium samples and $4 \%$ for lumpy samples. Condensate is released evenly in all temperature stages: starting with low concentrations $(0.5 \%)$ at $\leq 200{ }^{\circ} \mathrm{C}$ and $1.5-3.0 \%$ at each subsequent temperature stage. The total weight loss in all experiments is comparable and amounts to $21.74-23.32 \%$ of the initial mass of the sample. This value is composed of the mass of sublimate condensate (within 7.12-9.04\%) and the gas component (within 13.85$14.62 \%$ ). This series of experiments is characterized by the absence of swelling and an increase in the volume of the material. After each stage, starting from $300{ }^{\circ} \mathrm{C}$, sintering of the material in the bottom part of the crucible was observed with preservation of the upper free-flowing layer.

Table 2

The results of experiments with heating and exposure (1 hour) at $600{ }^{\circ} \mathrm{C}$ samples of Tavantolgoysky coal

\begin{tabular}{|c|l|c|c|c|c|c|}
\hline $\begin{array}{r}\text { Ex. } \\
\text { No. }\end{array}$ & \multicolumn{1}{|c|}{ Material } & $t,{ }^{\circ} \mathrm{C}$ & $\sum \Delta m, \%$ & Condensate, $\%$ & Gas. fraction, \% & Note \\
\hline 1 & Average sample & 600 & 24.6 & 7.9 & 16.7 & Swelling, sintering \\
\hline 2 & Average sample & 600 & 25.45 & 9.3 & 16.15 & Swelling, sintering \\
\hline 3 & Average sample & 600 & 20.7 & 8.73 & 12 & Swelling, sintering \\
\hline 4 & Trifle from the package & 600 & 10.45 & 8.9 & 1.6 & No swelling, sintering \\
\hline 5 & Monolith sample & 600 & 20.35 & 10.09 & 10.26 & Porous sinter \\
\hline 6 & Average $\sum$ exp. 1-3;5 & 600 & 22.78 & 9 & 13.78 & Swelling, sintering \\
\hline
\end{tabular}

The results of experiments on thermal decomposition of the coal batch under study are summarized in Table 2. As follows from the data presented, the results of all experiments (with and without stage aging) correlate well with each other, with the exception of experience data with breakdown of the bulk material (experiment 5), where the amount of condensate is comparable to average values ( $8.9 \%$ ), and the amount of gas fraction is an order of magnitude less $(1.6 \%)$. As a result, the total mass loss for this sample during thermal decomposition is $10.45 \%$. This is less than half the weight loss of the averaged samples and the monolith sample.

It should be noted that the characteristic feature of the behavior of this type of coal during its thermal decomposition is that the volume of the material increases 1.5-2.0 times when heated in continuous mode to $\geq 600^{\circ} \mathrm{C}$ and at the same time with step-by-step temperature exposures this phenomenon is not observed, but the sintering of the material in the bottom part is preserved. Apparently, this is due to the drainage of the liquid fractions during their formation and subsequent heating.

\section{Conclusions}

A preliminary thermal analysis of samples of coal VIII and IV of the layers showed that when they are heated, the gaseous components of the coal are distilled, and the solid hydrocarbons are sequentially melted 
and sublimated. The depth and quantitative characteristics of thermolysis are largely determined by the initial state of aggregation (size of material, preparation conditions, heating mode and the final temperature of the experiment). So, a fine sample of reservoir VIII with DTGA up to $660-700{ }^{\circ} \mathrm{C}$ has a relatively low mass loss (13-15\%). A sample of the original lump monolith of coal seam IV has a slightly different pattern of thermal decomposition. The DTA curve shows more prominently the effects of gas component sublimation, melting, sublimation, and burning at the crucible outlet of the hydrocarbon solid phases. In this case, the mass loss reaches $26 \%$.

Comparison of DTGA data from initial samples of a finely dispersed formation VIII and a large-size formation IV indicates a sharp difference in the content of the gas component in them ( 2 times). This is probably due to more affordable storage conditions for diffusion from the material of the gas component of the dispersed coal product of the sample from reservoir VIII, rather than lump material from the sample from formation IV.

The studies carried out of the enlarged batch showed that the thermal decomposition of hard coal from the Tavantolgoyskoye deposit was determined by the initial aggregate state of the samples, i.e. the size of the material, as well as the final temperature of thermolysis.

The total weight loss during thermal decomposition of the averaged samples of the starting material with continuous heating to $600^{\circ} \mathrm{C}$ and exposure for 2 hours at this temperature is in the range of $20.35-25.45 \%$. It consists of the mass of the condensate formed sublimates (7.90-10.09\%) and the magnitude of the gas component (10.26-16.70\%).

The data on thermal decomposition of a sample prepared from a fine, loose part of batch material differs sharply from those for averaged samples at close concentrations of sublimates concentrates $(8.9 \%)$ and almost an order of magnitude (1.6\%) less than the gas component. This is consistent with the data obtained during thermolysis of a single dispersed sample of reservoir VIII.

The total decrease in the mass of the samples in experiments with a stepwise temperature exposure $(21.74-23.32 \%)$ is comparable with the data obtained with continuous heating. This value is composed of the mass of sublimate condensate (7.12-9.04\%) and the gas component (13.85-14.62\%). The process of thermolysis begins already at $\leq 250^{\circ} \mathrm{C}$ and intensively develops at $400-500{ }^{\circ} \mathrm{C}$. With continuous heating, sintering and intensive swelling of the material occurs, its volume increases by $\sim 1.5-2.0$ times. The material is a porous, dry product with a denser bottom part. With stage-by-stage aging, starting at $300{ }^{\circ} \mathrm{C}$ and at all subsequent stages, the material is sintered in the bottom part, and in the upper part the bulk structure is preserved at the initial sample volume. From the results of the research it follows that the coals of the Tavantolgoyskoye deposit can be used for briquetting (without any addition of binders) and obtaining valuable coal-chemical products.

\section{References}

1 Горная энциклопедия: в 5 т. — Т. 5. / под ред. Е.А. Козловского. — М.: Сов. энцикл., 1991. — С. 227.

2 Краткая химическая энциклопедия: в 5 т. - Т. 2, 5. / под ред. И.Л. Кнунянца. — М.: Сов. энцикл., 1963-1967. C. 330,326 .

3 Геология Монгольской Народной Республики / под ред. Н.А. Миронова, Р.А. Хасина, Ч. Хурц. — М.: Недра, 1977.

4 Erdenetsogt, Bat-Orshikh Mongolian coal-bearing basins: Geological settings, coal characteristics, distribution, and resources / Bat-Orshikh Erdenetsogt, Insung Lee, Delegiin Bat-Erdene, Luvsanchultem Jargal // Int. Coal geol. — 2009. — Vol. 80, Iss. 2. — P. 87.

5 Шибанов В.И. Обобщение результатов геологоразведочных работ по Улуг-Хемскому угольному бассейну по состоянию на 01.01.1993. — Кызыл: ТТФГИ, 1994. — 33 с.

6 Копылов Н.И. Термическое разложение углей Тувинского месторождения / Н.И. Копылов // Химия в интересах устойчивого развития. - 2013. - Т. 21, № 1. - С. 1-6.

7 Kopylov N.I. Thermolysis of brown coal from the Baganursky deposit (Mongolia) / N.I. Kopylov // Bulletin of the Karaganda University. Chemistry series. — 2017. - No. 4(88). - P. 80-87.

8 Kopylov N.I. Thermolysis of coal from the deposits of Tuva and Mongoliya // Theoretical and experimental chemistry: Proceedings of the $\mathrm{VI}^{\text {th }}$ International scientific conference, dedicated to EXPO-2017 (15-17 June 2017). - Karaganda: KSU Publ., 2017. - P. 120. 


\title{
Н.И. Копылов
}

\section{Монғолияның Тавантолгой кен орны тас көмірлерінің күйдіру кезіндегі фазалық ыдырауы}

\begin{abstract}
Тавантолгой кен орнының тас көмірлері, басқа кен орындары көмірлері сияқты, отын-энергетикалық ресурс тұрғысынан, сонымен қатар металлургия және химия өнеркәсібінде шикізат ретінде үлкен қызығушылық туғызады. Қоршаған ортаның улы заттармен ластануын алдын алу мақсатында бұл көмірді ЖЭС және тұрмыстық пеш қондырғылары үшін отын ретінде және өнеркәсіпте бастапқы шикізат ретінде пайдалану кезінде арнайы дайындықтан өткізуді қажет етеді. Сондықтан көмірдің күйдіру кезіндегі фазалық ыдырауы зерттелді. Тавантолгой кен орнындағы тас көмірдің термиялық ыдырау зерттеулерінің нәтижелері көрсетілген. Зерттеудің нәтижесінде фазалық ыдырау процесі 300$500^{\circ} \mathrm{C}$ температурасы аралығында газ, тез балқитын және жылдам қайнайтын фазалардың бөлінуімен жүретіні анықталды. Бұл кезде материал массасының көлемі бойынша артатындығы және қатты, кеуекті өнім түзіп бірігетіні байқалды, оның көлемі бастапқы сынамадан 1,5-2 есе артатыны анықталды. Тавантолгой көмірлерін байланыстырғыш заттарды қоспай отындық брикеттерді алуда қолдануға болатындығы көрсетілді.
\end{abstract}

Кілт сөздер: тас көмір, фазалық ыдырау, қатты қалдық, шайырлы фракция, конденсат, возгондар, органикалық фракция.

\section{Н.И. Копылов \\ Фазовое разложение каменных углей Тавантолгойского месторождения Монголии при их обжиге}

\begin{abstract}
Каменные угли Тавантолгойского месторождения по аналогии с углями других подобных месторождений представляют интерес не только как топливно-энергетический ресурс, но и как сырьё для металлургической и химической отраслей промышленности. В целях предотвращения заражения окружающей среды токсичными компонентами при использовании этих углей в качестве топлива для ТЭЦ и бытовых печных установок, а также в промышленности в качестве исходного сырья, требуется их специальная подготовка. В связи с этим были проведены исследования по изучению фазового разложения этих углей при их обжиге. Представлены результаты комплексного исследования термического разложения каменных углей данного месторождения. Установлено, что этот процесс фазового разложения осуществляется в пределах температур $300-500{ }^{\circ} \mathrm{C}$ с выделением газовой, легкоплавкой и легкокипящей фаз. При этом масса материала увеличивается в объёме и спекается с образованием твёрдого, пористого спёка, объём которого в 1,5-2 раза превышает объём исходной пробы. Показано, что тавантолгойские угли можно использовать для получения топливных брикетов без добавок связующего.
\end{abstract}

Ключевые слова: каменный уголь, фазовое разложение, твёрдый остаток, смолистая фракция, конденсат, возгоны, органическая фракция.

\section{References}

1 Kozlovsky, E.A. (Eds.). (1991). Hornaia entsiklopediia [Mountain Encyclopedia] (Vols. 1-5: Vol. 5). Moscow: Sovetskaia entsiklopediia [in Russian].

2 Knunyats, I.L. (Eds.). (1963-1967). Kratkaia khimicheskaia entsiklopediia [Brief chemical encyclopedia]. (Vols. 1-5: Vol. 2, 5). Moscow: Sovetskaia entsiklopediia [in Russian].

3 Mironova, O.N., Hasina, R.A., \& Hurz, C. (1977). Heolohiia Monholskoi Narodnoi Respubliki [Geology of the Mongolian People's Republic]. Moscow: Nedra [in Russian].

4 Erdenetsogt, B.-O., Lee, I., Delegiin, B.-E., \& Jargal, L. (2009). Mongolian coal-bearing basins: Geological settings, coal characteristics, distribution, and resources, Int. Coal geol., 80(2), 87.

5 Shibanov, V.I. (1994). Obobshchenie resultatov heolohorazvedochnykh rabot po Ulug-Khemskomu uholnomu basseinu po sostoianiiu na 01.01.1993 [Generalization of the results of geological exploration of the Ulug-Khemky coal basin as of 01/01/1993]. Kyzyl: TTFGI [in Russian].

6 Kopylov, N.I. (2013). Termicheskoe razlozhenie uhlei Tuvinskoho mestorozhdeniia [Thermal decomposition of coal from the Tuva deposit]. Khimiia v interesakh ustoichivoho razvitiia - Chemistry for Sustainable Development, 21, 1, 1-6 [in Russian].

7 Kopylov, N.I. (2017). Thermolysis of brown coal from the Baganursky deposit (Mongolia). Bulletin of the Karaganda University. Chemistry series, (4)88, 80-87.

8 Kopylov, N.I. Thermolysis of coal from the deposits of Tuva and Mongoliya. Proceedings from Theoretical and experimental chemistry: the VI ${ }^{\text {th }}$ International scientific conference, dedicated to EXPO-2017, 15-17 June 2017 (p. 120). Karaganda: KSU Publ. 